\title{
Genetic Differentiation of Citrullus colocynthis (L.) Populations Depending on Allozyme Diversity
}

\author{
Shawkat M. Ahmed ${ }^{(1,2) \#}$ and Khalid H. Alamer ${ }^{(1)}$ \\ (1) Biology Department, Faculty of Science, Taif University, PO Box 5700,Taif, KSA; \\ (2) Biology Department, Faculty of Education, Ain Shams University, Cairo, Egypt.
}

\begin{abstract}
$\mathbf{C}$ ITRULLUS colocynthis (L.) is a desert plant having a large history in pharmaceutical industries as an important medicinal plant. Allozyme variation and population genetic structure of $C$. colocynthis in 6 natural populations from western region, Saudi Arabia, were investigated by 6 enzyme systems. The genetic differentiation within and among $C$. colocynthis populations has been revealed by allozyme analysis. Ten loci were monomorphic in all populations, whereas seven loci having two alleles ( $\alpha$-EST-1, $\beta$-EST-1, MDH- 1, ADH-4, ADH5, ALO-4 and PRX-2) were polymorphic. The mean allozyme variability indices within $C$. colocynthis populations $(P=31.17 \% ; A=1.21)$ were lower than those for insect-pollinated species $\left(P=34 \% ; A=2.67 ; H_{e}=0.205\right)$ except $H_{e}$ value $(0.415)$ was higher. The observed mean heterozygosity $\left(H_{o}=0.757\right)$ was higher than the expected mean heterozygosity $\left(H_{e}=0.415\right)$ indicating the existence of natural selection against homozygosity. The Inbreeding coefficient values $(F)$ of polymorphic loci were negative suggesting a significant excess of heterozygosity in the studied populations. The UPGMA dendrogram of 84 individuals of $C$. colocynthis confirmed the notable variability within populations. Differentiation among-population $\left(F_{S T}\right)$ recorded $16.2 \%$ of the total variation. Low $F_{S T}$ and high genetic distance $(D)$ values suggested a low differentiation among $C$. colocynthis populations. Little gene flow $\left(N_{m}\right)$ was deduced in all populations except ME based on the allozyme data. We suggest that population ME can be recommended for both genetic conservation and breeding programs.
\end{abstract}

Keywords: Citrullus, Allozyme, Population, Heterozygosity, Gene flow.

\section{Introduction}

Citrullus colocynthis L. (Cucurbitaceae), is a drought-resistant wild perennial herb that widely found in Africa and Asia. C. colocynthis has many medicinal advantages against various diseases such as diabetes II and breast cancer (Grossman et al., 2007 and Huseini et al., 2009). C. colocynthis grows fast in the sandy soil regions of Saudi Arabia under changeful environmental conditions (Chaudhary \& AL-jowaid, 1999). Although the wide distribution of $C$. colocynthis, our knowledge about its genetic diversity is very poor. Loss of genetic variation decreases the ability of wild species to survive fluctuations in climate, diseases, pollutants and natural enemies (Frankham, 1995). Genetic diversity and good management of its natural populations are needed for more adaptation and improvement in future. Isozymes are useful in the field of biochemical genetics and population genetics as biochemical markers (Wendel \& Weeden, 1989). Isozymes examined genetic variation and phylogenetic relationships in several Citrullus spp. by Navot \& Zamir (1987), Biles et al. (1989) and Navot et al. (1990), but most of them were monomorphic. However they will be useful and accurate when we examine more accessions and individuals than some DNA markers (Klaas, 1998; Levi et al., 2001b; Ritschel et al., 2004; Solmaz et al., 2010 and Minsart et al., 2011).

Few studies described the genetic variability and population structure in $C$. colocynthis using isozymes. The aim of this work is to estimate the genetic differentiation within and among six natural populations of $C$. colocynthis from western region of Saudi Arabia, based on isozyme polymorphism. This could be useful for conservation and breeding purposes.

\footnotetext{
"Corresponding author email: shamahmoh@gmail.com, Postal code: 5700, Phone +966535923238, Fax +966-2-7256620. Edited by: Prof. Dr. Soliman A. Haroun, Faculty of Science, Kafr El-Sheikh University, Kafr El-Sheikh, Egypt. 


\section{Materials And Methods}

\section{Plant materials}

Leaves of eighty four individuals of $C$. colocynthis (14 individuals in each of six populations studied) were collected for assessment of genetic variability. The six populations were collected from six sites from the western region of Saudi Arabia (Table 1).

\section{Isozymes}

The examined isozymes were: Alcohol dehydrogenase (ADH); (E.C. 1.1.1.1), aldehyde oxidase (ALO); (E.C.1.2.3.1), $\alpha$-and $\beta$-esterases (EST); (E.C.3.1.1.1), peroxidase (PRX); (E.C.1.11.1.7) and malate dehydrogenase (MDH); (E.C.1.1.1.37). Extraction of isozyme was carried out by homogenizing $1 \mathrm{~g}$ of fresh leaves in $1 \mathrm{ml}$ extraction buffer (1M Tris- $\mathrm{HCl}, \mathrm{pH} 8.8)$ then centrifuged at $10000 \mathrm{rpm}$ and the supernatant was separated using native-polyacrylamide gel electrophoresis method (Stegemann et al., 1985). Protocols of Scandalios (1964) for $\alpha$-and $\beta$-EST, Wendel \& Weeden (1989) for ALO, Weeden \& Wendel (1990) for ADH, Jonathan \& Wendell (1990) for MDH and Heldt (1997) for PRX were used for isozyme staining.

\section{Data analysis}

Parameters for detecting the within-populations genetic variation and the inbreeding coefficient; Wright's $F\left[F=\left(1-H_{o} / H_{e}\right)\right]$, were estimated as described by Hamrick \& Godt (1989) and Nei (1973) (Tables 3 and 4). Negative $F$ indices refers to tendency to heterozygosity whereas positive values indicate an inbreeding system of mating. Levels of significance among populations for each parameter were determined by t-test (Varghese et al., 1999). Parameters of populations genetic structure; $F_{I S}, F_{I T}$ and $F_{S T}$. were investigated by Wright's $F$-statistics (Wright,1965). Gene flow; $\mathrm{Nm}$, was calculated by Wright's (1951) equation with modification by Crow \& Aloki (1984): $F_{S T}=1 /\left(4 N_{m} \alpha+1\right)$ where $\alpha=[n /(n-1)]^{2}$ and $\mathrm{n}$ is the populations number. Isozyme frequency data were used to calculate genetic distance estimates according to Nei (1973). To discern the genetic variability within populations, each band of 84 individuals was coded as 1 for presence or 0 for absence. Clustering was performed using UPGMA procedure and represented in a phenogram by using SAHN and TREE modules, respectively, and it was also performed for studying the relationships among populations. The computer program NTSYS-pc 2.2 was used in all previous operations (Rohlf, 1998).

\section{Results}

Allele diversity

Polymorphisms were observed in all the six systems analyzed. A total of 31 alleles were detected among the 24 loci from 6 enzyme systems evaluated. The frequencies of them are demonstrated in Table 2. Ten loci ( $\alpha$-EST-2, $\alpha$-EST-3, $\alpha$-EST-4, $\alpha$-EST-5, $\beta$-EST-4, $\beta$-EST-5, $\mathrm{MDH}-2, \mathrm{ADH}-2, \mathrm{ADH}-3$ and PRX-3) were monomorphic in all populations, whereas seven loci having two alleles ( $\alpha$-EST-1, $\beta$-EST-1, MDH1, ADH-4, ADH-5, ALO-4 and PRX-2) were polymorphic in at least one population. The two loci; $\beta$-EST-3 and PRX-1 were only detected in populations TA and JE, respectively.

TABLE 1. Code, sample size (N) and sites of six natural populations of $C$. colocynthis from western region of Saudi Arabia.

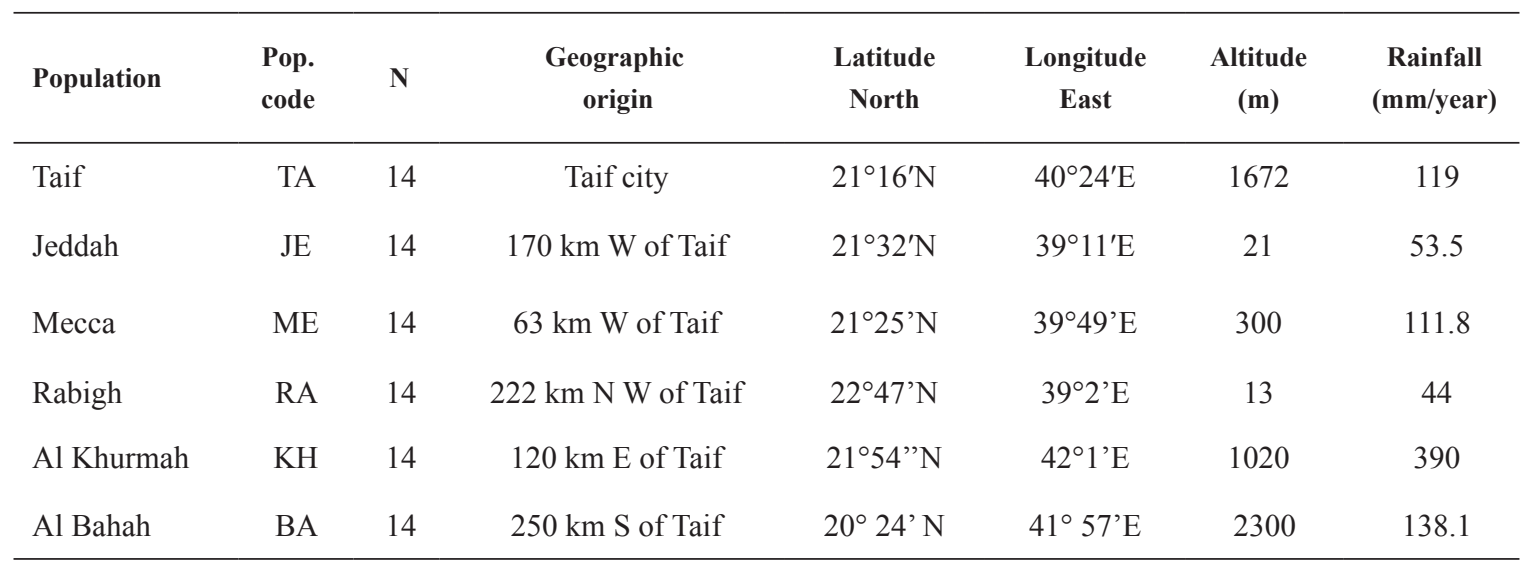


TABLE 2. Estimated allele frequencies at 24 loci in six population of $C$. colocynthis.

\begin{tabular}{|c|c|c|c|c|c|c|c|}
\hline \multirow{2}{*}{ Locus } & \multirow{2}{*}{ Alleles } & \multicolumn{6}{|c|}{ Population } \\
\hline & & JE & TA & ME & RA & KH & BA \\
\hline \multirow[t]{2}{*}{$\alpha$-EST-1 } & $\mathrm{a}$ & 0.50 & 0.00 & 0.50 & 0.00 & 0.50 & 0.50 \\
\hline & $\mathrm{b}$ & 0.50 & 0.00 & 0.50 & 0.00 & 0.50 & 0.50 \\
\hline$\alpha$-EST-2 & $\mathrm{a}$ & 1.00 & 1.00 & 1.00 & 1.00 & 1.00 & 1.00 \\
\hline$\alpha$-EST-3 & $\mathrm{a}$ & 1.00 & 1.00 & 1.00 & 1.00 & 1.00 & 1.00 \\
\hline$\alpha$-EST-4 & $\mathrm{a}$ & 1.00 & 1.00 & 1.00 & 1.00 & 1.00 & 1.00 \\
\hline$\beta$-EST-1 & $\mathrm{b}$ & 0.50 & 0.50 & 0.00 & 0.50 & 0.50 & 0.00 \\
\hline$\beta$-EST- 2 & $\mathrm{a}$ & 1.00 & 1.00 & 0.00 & 0.00 & 0.00 & 0.00 \\
\hline$\beta$-EST-3 & $\mathrm{a}$ & 0.00 & 1.00 & 0.00 & 0.00 & 0.00 & 0.00 \\
\hline$\beta$-EST-4 & $\mathrm{a}$ & 1.00 & 1.00 & 1.00 & 1.00 & 1.00 & 1.00 \\
\hline$\beta$-EST-5 & $\mathrm{a}$ & 1.00 & 1.00 & 1.00 & 1.00 & 1.00 & 1.00 \\
\hline ADH-2 & $\mathrm{a}$ & 1.00 & 1.00 & 1.00 & 1.00 & 1.00 & 1.00 \\
\hline ADH-3 & $\mathrm{a}$ & 1.00 & 1.00 & 1.00 & 1.00 & 1.00 & 1.00 \\
\hline \multirow[t]{2}{*}{ ADH-4 } & $\mathrm{a}$ & 0.50 & 0.50 & 0.50 & 0.50 & 0.50 & 0.50 \\
\hline & $\mathrm{b}$ & 0.50 & 0.50 & 0.50 & 0.50 & 0.50 & 0.50 \\
\hline \multirow[t]{2}{*}{ ADH-5 } & $\mathrm{a}$ & 0.36 & 0.00 & 0.63 & 0.86 & 0.93 & 1.00 \\
\hline & $\mathrm{b}$ & 0.64 & 1.00 & 0.37 & 0.14 & 0.07 & 0.00 \\
\hline ALO-1 & $\mathrm{a}$ & 1.00 & 1.00 & 1.00 & 1.00 & 1.00 & 0.00 \\
\hline ALO-2 & $\mathrm{a}$ & 1.00 & 1.00 & 1.00 & 1.00 & 1.00 & 0.00 \\
\hline ALO-3 & $\mathrm{a}$ & 1.00 & 1.00 & 1.00 & 1.00 & 1.00 & 0.00 \\
\hline \multirow[t]{2}{*}{ ALO-4 } & $\mathrm{a}$ & 0.71 & 0.93 & 1.00 & 0.93 & 1.00 & 0.89 \\
\hline & $\mathrm{b}$ & 0.29 & 0.07 & 0.00 & 0.07 & 0.00 & 0.11 \\
\hline
\end{tabular}

\section{Genetic variation within populations}

Parameters of genetic variability showed considerable level of genetic variation within populations (Table 3). $A$ ranged from 1.14 in population $\mathrm{ME}$ to 1.30 in population $\mathrm{KH}$ with a mean of 1.21 alleles per locus, whereas the mean of $A_{p}$ was 1.72 , ranging from 1.56 in populations $\mathrm{KH}$ to 1.97 in population ME. $P$ ranged from $25.0 \%$ in population TA to $35.3 \%$ in population BA with a mean of $31.17 \%$. $H_{o}$ ranged from 0.636 in population $\mathrm{RA}$ to 0.938 in population $\mathrm{ME}$, whereas the range of $H_{e}$ was from 0.358 in population $\mathrm{KH}$ to 0.492 in population ME. The observed heterozygosities were higher than those expected in all populations. Obviously population ME possessed the highest level of genetic variation $H_{e}$, while populations RA and $\mathrm{KH}$ had rather lower levels of genetic variation. The mean observed heterozygosity was higher than that expected, with values of 0.757 and 0.415 , respectively. The UPGMA dendrogram (Fig. 1) obtained using the 33 isozyme bands scored in the 84 individuals, showed a notable variability within populations examined. At coefficient 0.59 , ten groups were formed, five of them; G1, G3, G4, G5 and G6, corresponded to populations JE, RA, BA,
$\mathrm{ME}$ and $\mathrm{KH}$, respectively. Most of the individuals of the same population grouped together, except population TA, which presented lower similarity values among individuals, representing the higher genetic diversity within population.

The $F$ values of all loci were lower than zero. One exception; locus PRX-2 in population $\mathrm{KH}$ was greater than zero reflecting a deficiency of heterozygosity (Table 4). The Inbreeding coefficient ranged from -0.902 in population ME to -0.578 in population RA with mean value of -0.602 . Obviously, C. colocynthis populations revealed an excess of heterozygosity.

\section{Genetic variation among populations}

$\mathrm{F}_{I S}$ and $F_{I T}$ estimates were generally negative. $F_{I S}$ ranged from -0.958 for population $\mathrm{ME}$ to -0.60 for population RA, and averaged -0.788 , indicating significant excess of heterozygosity in the populations, which was in accordance with the values of $F$ mentioned above. $F_{S T}$ ranged from 0.008 for population ME to 0.306 for population $\mathrm{KH}$, with a mean of 0.162 , indicating that $16.2 \%$ of the total genetic variation exists among populations. 
TABLE 3. Genetic variability estimates within $C$. colocynthis populations.

\begin{tabular}{lccccc}
\hline Population & $\mathbf{P}$ & $\mathbf{A}$ & $\mathbf{A}_{\mathbf{P}}$ & $\mathbf{H}_{\mathbf{o}}$ & $\mathbf{H}_{\mathbf{e}}$ \\
\hline $\mathrm{JE}$ & 31.8 & 1.27 & 1.85 & 0.816 & 0.458 \\
$\mathrm{TA}$ & 25.0 & 1.20 & 1.69 & 0.785 & 0.408 \\
$\mathrm{ME}$ & 33.3 & 1.14 & 1.97 & 0.938 & 0.492 \\
$\mathrm{RA}$ & 26.3 & 1.16 & 1.58 & 0.636 & 0.367 \\
$\mathrm{KH}$ & 35.0 & 1.30 & 1.56 & 0.647 & 0.358 \\
$\mathrm{BA}$ & 35.3 & 1.18 & 1.69 & 0.720 & 0.409 \\
Among-population mean & 31.17 & 1.21 & 1.72 & 0.757 & 0.415 \\
SE & 1.81 & 0.03 & 0.06 & 0.047 & 0.021 \\
$t$-value & $17.2^{* * *}$ & $46.7^{* * *}$ & $26.6^{* * *}$ & $16.2^{* * *}$ & $19.6^{* * *}$ \\
\hline
\end{tabular}

-P $(<0.99)$ percentage of polymorphic loci; $A$ average number of alleles per locus; $A_{p}$ average effective number of alleles per locus; $H$ observed heterozygosity; $H_{e}$ expected heterozygosity under Hardy-Weinberg equilibrium; $F$ Fixation Index (Inbreeding Coefficient); SE the standard error.

-ns $\mathrm{P}>0.05$; ** $\mathrm{P}<0.01$; *** $\mathrm{P}<0.001$.

TABLE 4. Inbreeding coefficient values (F) for polymorphic loci in $C$. colocynthis populations.

\begin{tabular}{lcccccc}
\hline Locus & JE & TA & ME & RA & KH & BA \\
\hline$\alpha$-EST-1 & -1 & - & -1 & - & -1 & -1 \\
$\beta$-EST-1 & -1 & -1 & - & -1 & -1 & - \\
MDH-1 & -1 & -1 & -1 & -0.609 & -0.516 & -0.516 \\
ADH-4 & -1 & -1 & -1 & -1 & -1 & -1 \\
ADH-5 & -0.540 & - & -0.609 & -0.203 & -0.077 & - \\
ALO-4 & -0.383 & -0.077 & - & -0.077 & - & -0.007 \\
PRX-2 & -0.295 & - & - & - & 0.079 & - \\
Mean & -0.745 & -0.769 & -0.902 & -0.578 & -0.586 & -0.631 \\
\hline
\end{tabular}

Average genetic distance $(D)$ values ranged from 0.240 to 0.468 with a mean of 0.325 (Table 5). Consequently, Nei's genetic distances $(D)$ and geographic distances were estimated among pairs of $C$. colocynthis populations as illustrated in Table 6. On the basis of these genetic distance values, UPGMA cluster analysis showed the genetic relationship of the populations studied through a dendrogram (Fig. 2). Two principal groups were found in the cluster analysis. The first cluster was made up of population JE, TA and BA and the second was formed by the other populations. It appeared that populations of closest geographic proximity could not be clustered together. This was also confirmed statistically by correlation analysis on Nei's genetic distance and geographic distance $(r=-0.013 ; p=0.980)$. The gene flow $\left(N_{m}\right)$ values ranged between 0.57 and 2.35 in all populations except that of population ME (Table $5)$. The genetic uniqueness of each population was estimated by $F_{S T}, D$ and $N_{m}$ (Table 5). Lower values of $F_{S T}, D$ and higher $N_{m}$ were obtained for the analyses of population $\operatorname{ME}(0.008,0.243,31.0)$ than those for all 6 populations $(0.162,0.325$, 6.83 ), respectively. It could be concluded that population ME had some unique genetic features and being suitable for conservation process. 


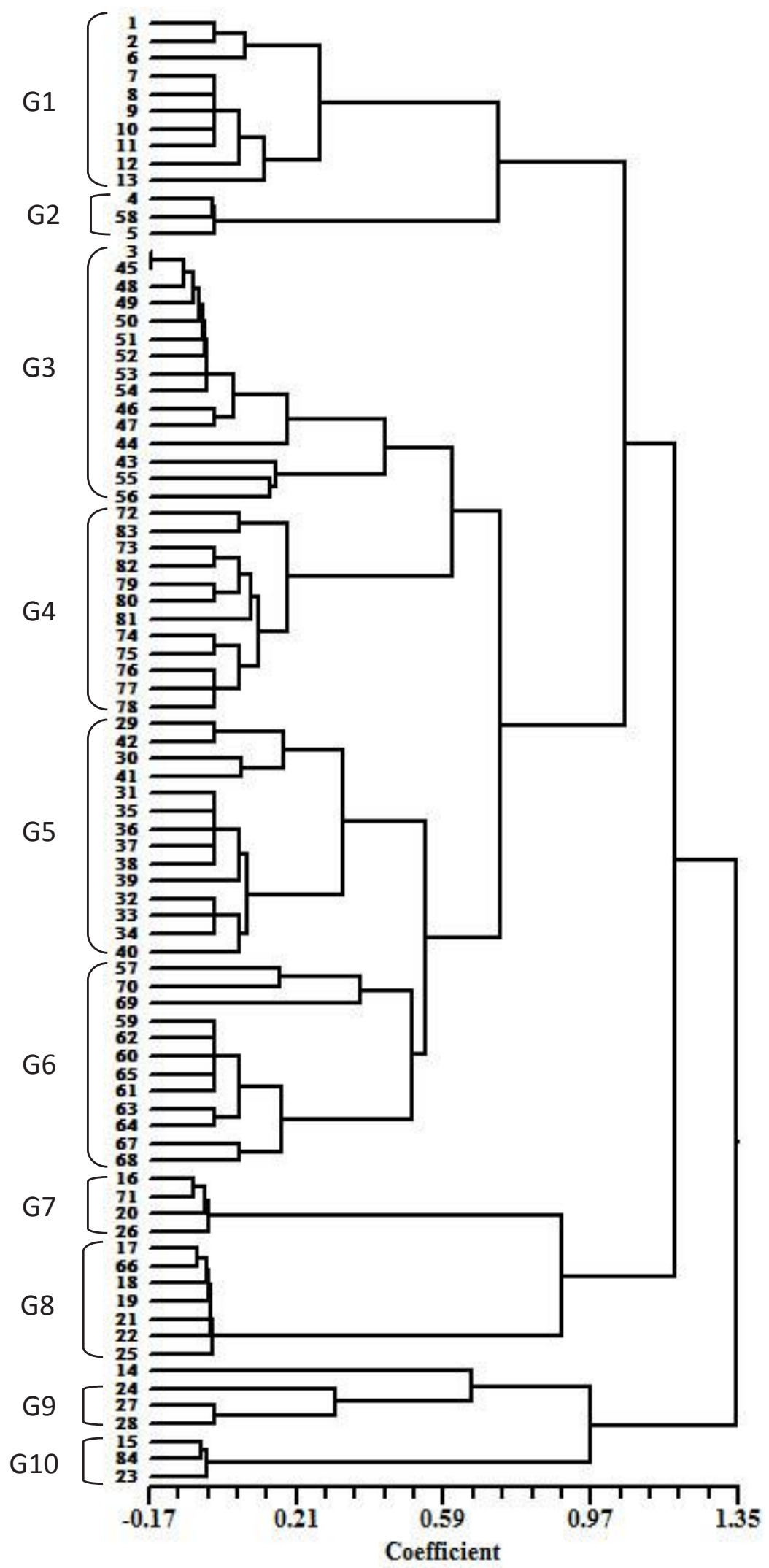

Fig. 1. The dendrogram of 84 individuals of $C$. colocynthis generated by UPGMA analysis. 


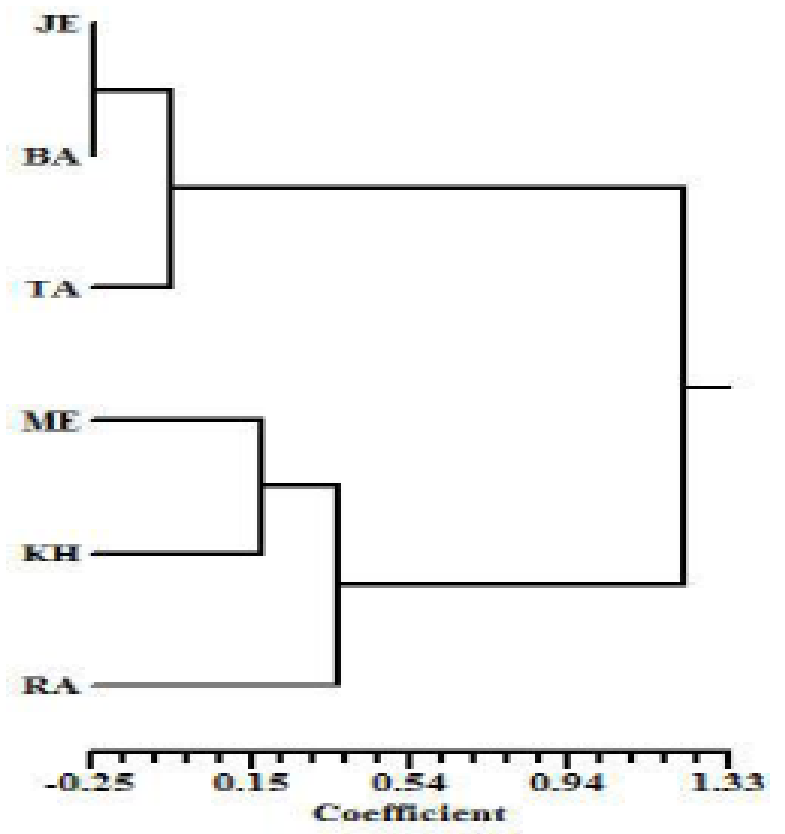

Fig. 2. The UPGMA dendrogram of the six populations of $C$. colocynthis based on the Nei's genetic distances.

TABLE 5. F-statistics, average Nei's genetic distance and gene flow values in $C$. colocynthis populations.

\begin{tabular}{|c|c|c|c|c|c|c|c|c|}
\hline \multirow[b]{2}{*}{ Pop. } & \multicolumn{6}{|c|}{ F-statistics } & \multirow{2}{*}{$\begin{array}{c}\begin{array}{c}\text { Genetic } \\
\text { distance }\end{array} \\
\text { D }\end{array}$} & \multirow{2}{*}{$\begin{array}{c}\begin{array}{c}\text { Gene } \\
\text { flow }\end{array} \\
N_{m}\end{array}$} \\
\hline & $\mathbf{H}_{\mathbf{I}}$ & $\mathbf{H}_{\mathrm{s}}$ & $\mathbf{H}_{\mathrm{T}}$ & $\mathbf{F}_{\text {IS }}$ & $F_{\text {IT }}$ & $\mathbf{F}_{\mathrm{ST}}$ & & \\
\hline $\mathrm{JE}$ & 0.753 & 0.443 & 0.490 & -0.699 & -0.537 & 0.096 & 0.354 & 2.35 \\
\hline TA & 0.754 & 0.394 & 0.500 & -0.914 & -0.508 & 0.212 & 0.404 & 0.93 \\
\hline ME & 0.971 & 0.496 & 0.500 & -0.958 & -0.942 & 0.008 & 0.243 & 31.0 \\
\hline RA & 0.544 & 0.340 & 0.426 & -0.600 & -0.277 & 0.202 & 0.240 & 0.99 \\
\hline $\mathrm{KH}$ & 0.540 & 0.293 & 0.422 & -0.843 & -0.279 & 0.306 & 0.242 & 0.57 \\
\hline BA & 0.638 & 0.372 & 0.436 & -0.715 & -0.463 & 0.147 & 0.468 & 1.45 \\
\hline Mean & 0.700 & 0.389 & 0.462 & -0.788 & -0.501 & 0.162 & 0.325 & 6.21 \\
\hline $\mathrm{SE}$ & 0.067 & 0.029 & 0.016 & 0.057 & 0.099 & 0.042 & 0.040 & 4.96 \\
\hline$t$-test & $10.52 * * *$ & $13.16^{* * *}$ & $29.76^{* * *}$ & $-13.904 * * *$ & $-5.038 * *$ & $3.845^{*}$ & $8.098 * * *$ & $1.252^{\mathrm{ns}}$ \\
\hline \multicolumn{9}{|c|}{$\begin{array}{l}-F_{I S} \text { inbreeding coefficient within population; } F_{I T} \text { total inbreeding; } F_{S T} \text { genetic diversity among populations; } D \text { average genetic distance; } \\
N_{m} \text { gene flow calculated by Wright's model based on } F_{S T} ; \text { SE the standard error. } \\
\text {-ns } \mathrm{P}>0.05 ; * * \mathrm{P}<0.01 ; * * * \mathrm{P}<0.001 \text {. } \\
\text { TABLE 6. Geographical distances }(\mathbf{k m}) \text { (above diagonal) and Nei's genetic distances (below diagonal) among } C \\
\text { colocynthis populations. }\end{array}$} \\
\hline & & $\mathbf{J E}$ & TA & ME & $\mathbf{R}$ & & KH & $\mathbf{B A}$ \\
\hline $\mathrm{JE}$ & & & 133 & 65 & 16 & & 297 & 272 \\
\hline TA & & 0.241 & & 68 & 21 & & 166 & 187 \\
\hline $\mathrm{ME}$ & & 0.279 & 0.405 & & 17 & & 232 & 227 \\
\hline RA & & 0.354 & 0.297 & 0.133 & & & 324 & 400 \\
\hline $\mathrm{KH}$ & & 0.205 & 0.360 & 0.108 & & & & 220 \\
\hline BA & & 0.692 & 0.715 & 0.288 & & & 0.381 & \\
\hline
\end{tabular}




\section{Discussion}

Considerable genetic variation in the six populations of $C$. colocynthis was detected using allozymes, although many researchers predicted low levels of genetic diversity in species having small numbers of individuals and limited ranges (Drury, 1974). The mean allozyme variability indices of $C$. colocynthis within populations $(P=31.17 \% ; A=1.21)$ were lower than those of Hamrick \& Godt (1997) for insect-pollinated species $\left(P=34 \% ; A=2.67 ; H_{e}=0.205\right)$ except $H_{e}$ value $(0.415)$ was higher. The two $P$ and $A$ estimates were also much lower than those of the four cucurbits; Cucurbita argyrosperma ssp. sororia (100\% - 2.08), Cucurbita argyrosperma ssp. argyrosperma $(93 \%$ - 2.5), Cucurbita moschata (97\% - 2.06) and Cucurbita pepo $(92 \%-2.08)$ (Montes-hernandez \& Eguiarte, 2002). Whereas, our $P, A$ and $H_{e}$ values were higher than those of Cucurbita pepo and Cucurbita maxima (Deckerwalters et al., 1990), Cucumeropsis mannii and Langenaria siceraria (Koffi et al., 2008 and 2009). In all populations the values of $H_{o}$ were higher than $H_{e}$ reflecting excess in heterozygosity that was also confirmed by negative inbreeding coefficient $(F)$ values for polymorphic loci. These results conflicted the hypothesis of Biles et al. (1989) and Levi et al. (2001a) that the genus Citrullus had a narrow genetic basis, but they were in consistent with Mujaju \& Nybom (2011) and Shaik et al. (2015) who found that the diversity was higher in the wild species $C$. colocynthis than $C$. lanatus. This outcome confirmed the hypothesis that the species widely distributed, as C. colocynthis, have a higher genetic diversity percentage $\left(H_{e}\right)$ than geographically limited species (Hamrick et al., 1992). The greater allelic diversity within populations suggesting elimination of homozygotes from C. colocynthis populations by natural selection and possessing either mating systems characterized by a mixture of self-fertilization and outcrossing (Schoen \& Clegg, 1984) or a mode of insect-mediated crosspollination which promoted random mating (Wright, 1951). Previous investigations showed that some species of family Cucurbitaceae had mostly an outcrossing mating system that maintained genetic variation within their populations (Costich \& Meagher, 1992 and Montes-hernandez \& Eguiarte, 2002).

The $F_{I S}$ and $F_{I T}$ values were negative and revealed an excess of heterozygosity for all populations. The genetic differentiation among $C$. colocynthis populations $\left(F_{S T}=0.162\right)$ was similar to that detected for the animal-pollinated plants $\left(F_{S T}=0.187\right)$ (Hamrick, 1989), but lower than the averages for insect-pollinated species $\left(F_{S T}=0.245\right)$ and wind-pollinated species $\quad\left(F_{S T}=0.238\right)$ (Crawford et al., 2001). Similar results were obtained by Koffi et al. (2008 and 2009) who recoded low level of genetic variation among accessions and cultivars of Cucumeropsis mannii and Lagenaria siceraria compared to the genetic diversity within them. This was in harmony with Hamrick \& Godt (1996) and Nybom (2004) who mentioned that species with outcrossing mating system have lower genetic differentiation among populations compared with systems of selfing mating. There was no significant correlation between geographic distance and genetic distance $(D)$. Estimates of gene flow indicated low levels of migration among C. colocynthis populations except for population ME. Estimate of $N m>4$ suggests that gene flow in population ME was enough to face the effects of genetic drift (Kang \& Chung, 1997). The extensive gene flow could be attributed to its biological properties, especially its seed dispersal by insects (Dane et al., 2007). However, it appeared that genetic drift might have occurred in other populations which recorded fewer estimates of $\mathrm{Nm}$.

\section{Conclusions}

Allozyme markers were powerful to reveal variability in $C$. colocynthis. The mean estimate of $F_{S T}(16.2 \%)$ indicated that up to $83 \%$ of the total genetic variation existed within $C$. colocynthis populations. Therefore, we suggest fewer populations but more individuals within populations for its breeding work. The lack of significant correlation between genetic distance and geographic distance suggested that when sampling populations, it is not necessary to arrange sites identically within the area under study and the population must be selected only if it has high genetic variation. Furthermore, analyses of genetic uniqueness demonstrated that population ME is genetically unique and should also be paid additional interest for conservation purposes.

\section{References}

Biles, C.L., Martyn, R.D. and Wilson, H.D. (1989) Isozymes and general proteins from various 
watermelon cultivars and tissue types. Hort. Science, 24, 810-812.

Chaudhary, S.A. and Al-Jowaid, A.A. (1999) "Vegetation of the Kingdom of Saudi Arabia". National Agriculture and Water Research Center, Ministry of Agriculture and Water, Riyadh, KSA.

Costich, D.E. and Meagher, T.R. (1992) Genetic variation in Ecballium elaterium: Breeding system and geographic distribution. Journal of Evolutionary Biology, 5, 589-601.

Crawford, D.J., Ruiz, E., Stuessy, T.F., Tepe, E., Aqeveque, P., Gonzalez, F., Jensen, R.J., Anderson, G.J., Bernardello, G., Baeza, C.M., Swenson, U. and Silva, M. (2001) Allozyme diversity in endemic flowering plant species of the Juan Fernandez Archipelago, Chile: Ecological and historical factors with implications for conservation. American Journal of Botany, 88(12), 2195-2203.

Crow, J.F. and Aloki, K. (1984) Group selection for a polygenic behavioral trait: estimating the degree of population subdivision. Proceedings of the National Academy of Sciences of the United States of America 81, 6073-6077.

Dane, F., Liu, J. and Zhang, C. (2007) Phylogeography of the bitter apple, Citrullus colocynthis. Genetic Resources and Crop Evolution, 54, 327-336.

Decker-Walters, S.D., Walters, T.W., Posluszny, U. and Kevan, P.G. (1999) Genealogy and gene flow among annual domesticated species of Cucurbita. Canadian Journal of Botany, 68, 782-789.

Drury, W.H. (1974) Rare species. Biological Conservation, 6, 162-169.

Frankham, R. (1995) Conservation genetics. Annual Review of Genetics, 29, 305-327.

Grossman, S., Dovrat, S., Gottlieb, H.E. and Bergman, M. (2007) Growth inhibitory activity of cucurbitacinglucosides isolated from Citrullus colocynthis on human breast cancer cells. TanninSpitz T. Biochemical Pharmacology, 73(1), 56-67.

Hamrick, J.L. (1989) Isozymes and the analysis of genetic structure in plant populations. In: "Advances in Plant Sciences Series", pp. 87-105. DE Soltis and PS Soltis (Ed.), Dioscorides Press, Portland, Oregon, USA.
Hamrick, J.L. and Godt, M.J.W. (1989) Allozyme diversity in plant species. In: "Plant Population Genetics, Breeding, and Genetic Resources", A.H.D. Brown, M.T. Clegg, A.L. Kahler and B.S. Weir (Ed.), pp. 43-63. Sinauer Associates Inc., Massachusetts, USA.

Hamrick, J.L. and Godt, M.W. (1996) Conservation genetics of endemic plant species. In: "Conservation Genetics: Case Studies from Nature", J.C. Avise and J.L. Hamrick (Ed.), pp. 281-304. Chapman and Hall, New York, USA.

Hamrick, J.L. and Godt, M.J.W. (1997) Effects of life history traits on genetic diversity in plant species. In: "Plant Life Histories-ecology, Phylogeny and Evolution", J. Silvertown, M. Franco and J.L. Harper (Ed.), pp. 102-118. Cambridge University Press, Cambridge, UK.

Hamrick, J.L., Godt, M.J.W. and Sherman-Broyles, S. (1992) Factors influencing levels of genetic diversity in wood plant species. New Forest, 6, 95-24.

Heldt, W.H. (1997) A leaf cell consists of several metabolic compartments. "Plant Biochemistry and Molecular Biology". Oxford Univ. Press, Oxford, UK.

Huseini, H.F., Darvishzadeh, F., Heshmat, R., Jafariazar, Z. and Raza, L.M. (2009) The clinical investigation of Citrullus colocynthis (L.) Schrad. fruit in treatment of Type II diabetic patients: A randomized, double blind, placebo-controlled clinical trial. Phytotherapy Research, 23(8), 1186-1189.

Jonathan, F.W. and Wendell, N.F. (1990) Visualization and interpretation of plant allozyme. In: "Allozymes in Plant Biology", D.E. Sdtis, and P.S. Sottis (Ed.), pp. 5-45. Champan and Hall Press, London, UK.

Kang, S.S. and Chung, M.G. (1997) Genetic variation and population structure in Korean endemic species: IV. Hemerocallis hakuunensis (Liliaceae). Journal of Plant Sciences, 110, 209-217.

Klaas, M. (1998) Applications and impact of molecular markers on evolutionary and diversity studies in Allium. Plant Breeding, 117, 297-308.

Koffi, K.K., Gbotto, A.A., Malice, M., Dje, Y., Bertin, P., Baudoin, J. and Zoro Bi, I.A. (2008) Morphological and allozyme variation in a collection of Cucumeropsis mannii Naudin (Cucurbitaceae) 
from Cote d'Ivoire. Biochemical Systematics and Ecology, 36, 777-789.

Koffi, K.K., Anzara, G.K., Malice, M., Djè, Y., Bertin, P., Baudoin, J. and Zoro Bi, I.A. (2009) Morphological and allozyme variation in a collection of Lagenaria siceraria (Molina) Standl. from Côte d'Ivoire. Biotechnology, Agronomy, Society and Environment, 13(2), 257-270.

Levi, A., Thomas, C.E., Keinath, A.P. and Wehner, T.C. (2001a) Genetic diversity among watermelon (Citrullus lanatus and Citrullus colocynthis) accessions. Genetic Resources and Crop Evolution, 48(6), 559-566.

Levi, A., Thomas, C.E., Wehner, T.C. and Zhang, X. (2001b) Low genetic diversity indicates the need to broaden the genetic base of cultivated watermelon. Hort. Science, 36(6), 1096-1101.

Minsart, L.A., Dje, Y., Baudoin, J.P., Jacquemart, A.L. and Bertin, P. (2011) Set up of simple sequence repeat markers and first investigation of the genetic diversity of West-African watermelon (Citrullus lanatus ssp. vulgaris oleaginous type). Genetic Resources and Crop Evolution, 58(6), 805-814.

Montes-Hernandez, S. and Eguiarte, L.E. (2002) Genetic structure and indirect estimates of gene flow in three taxa of Cucurbita (Cucurbitaceae) in western Mexico. American Journal of Botany, 89(7), 11561163.

Mujaju, C. and Nybom, H. (2011) Local-level assessment of watermelon genetic diversity in a village in Masvingo Province, Zimbabwe: Structure and dynamics of landraces on farm. African Journal of Agricultural Research, 6, 5822-5834.

Navot, N. and Zamir, D. (1987) Isozyme and seed protein phylogeny of the genus Citrullus (Cucurbitaceae). Plant Systematics and Evolution, 156 (1-2), 61-67.

Navot, N., Sarfatti, M. and Zamir, D. (1990) Linkage relationships of genes affecting bitterness and flesh color in watermelon. Journal of Heredity, 81,162165.

Nei, M. (1973) Analysis of gene diversity in subdivided populations. Proceedings of the National Academy of Sciences of the United States of America, 70, 3321-3323.
Nybom, H. (2004) Comparison of different nuclear DNA markers for estimating intraspecific genetic diversity in plants. Molecular Ecology, 13, 11431155 .

Ritschel, P.S., Lins, T.C., Tristan, R.L., Buso, G.S., Buso, J.A. and Ferreira, M.E. (2004) Development of microsatellite markers from an enriched genomic library for genetic analysis of melon (Cucumis melo L.). BMC Plant Biology, 4(1), 9-22.

Rohlf, F.J. (1998) NTSYSpc: Numerical Taxonomy and Multivariate Analysis System, version 2.02. Exeter Software, New York, USA.

Scandalios, J.C. (1964) Tissue-specific allozyme variations in maize. Journal of Heredity, 55, 281285.

Schoen, D.J. and Clegg, M.T. (1984) Estimation of mating system parameters when outcrossing events are correlated. Proceedings of the National Academy of Sciences of the United States of America, 81, 5258-5262.

Shaik, R.S., Gopurenko, D., Urwin, N.A.R., Burrows, G.E., Lepschi, B.J. and Weston, L.A. (2015) Population genetics of invasive Citrullusn lanatus, Citrullus colocynthis and Cucumis myriocarpus (Cucurbitaceae) in Australia: Inferences based on chloroplast and nuclear gene sequencing. Biological Invasions, 17, 2475-2490.

Solmaz, I., Sari, N., Aka-Kacar, Y. and Yalcin-Mendi, N.Y. (2010) The genetic characterization of Turkish watermelon (Citrullus lanatus) accessions using RAPD markers. Genetic Resources and Crop Evolution, 57(5), 763-771.

Stegemann, H., Afifiy, A.M.R. and Hussein, K.R.F. (1986) Identification of date (Phoenix dectylifera) cultivars by protein patterns. Phytochemistry, 26(1), 149-153.

Varghese, M., Edwards, M.A. and Hamrick, J.L. (1999) Genetic variation within two subspecies of Acacia nilotica. Forest Genetics, 6(4), 221-228.

Weeden, N.F. and Wendel, J.F. (1990) Genetics of plant isozymes. In: "Isozymes in Plant Biology", D.E. Soltis and P.S. Soltis (Ed.), pp. 46-72. Chapman and Hall Press, London, UK.

Wendel, J.F. and Weeden, N.F. (1989) Visualization and 
interpretation of plant allozymes. In: "Allozymes in Plant Biology, Advances in Plant Sciences", Soltis, D.E., Soltis, P.S. (Ed.), series 4, pp. 5-45. Dioscorides Press, Portland, OR, USA.

Wright, S. (1951) The genetical structure of populations. Annals of Eugenics, 15, 323-354.
Wright, S. (1965) The interpretation of population structure by F-statistics with special regard to systems of mating. Evolution, 19, 395-420.

(Received 19/ 4/2018; accepted 25/7/2018)

\title{
التمايز الوراثي لعثائر السبترولوس كولوسينثيس (الحنظل) اعتمادا على تنوع أليلات المشابهات الانزيمية

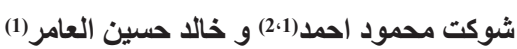 (1) قسم الاحياء ـ كلية العلوم - جامعة الطائف ـ السعودية و و (2)قنسم العلوم البيولوجية و الجيولوجية ـ كلية التربيةـ جامعة عين شمس ـ القاهره ـمصر.
}

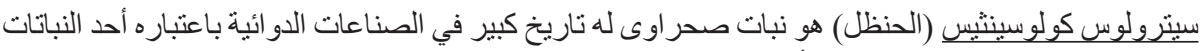

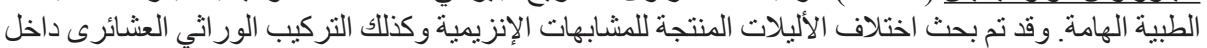

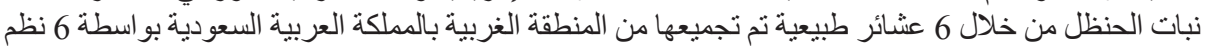

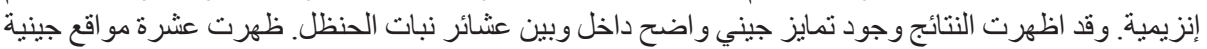
كمو اقع وحيدة المظهر فى كل العشائر، في حين اعتبرت سبعة أخرى -

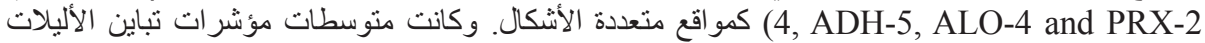

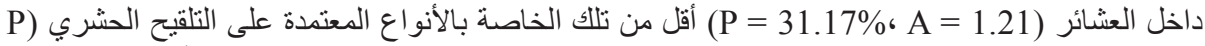

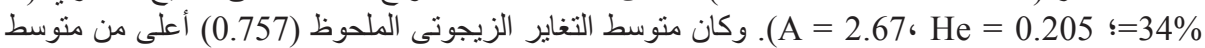

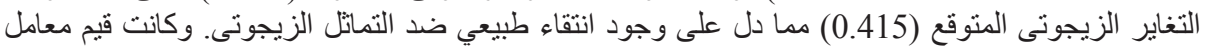

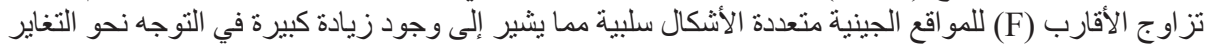

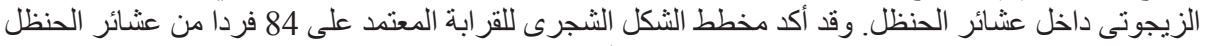

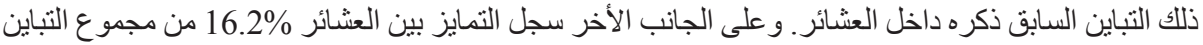

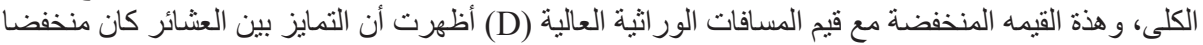

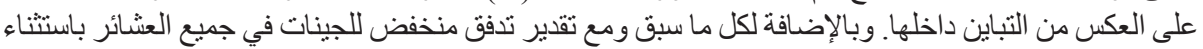

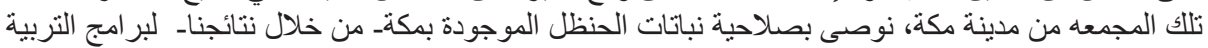
وحفظ الأصول الور اثية.

و تخلص الدر اسة إلى أهمية البيئة الصخرية القاحلة في سيناء كمصدر متميز للأكتينوبكتريا ذات قدر ات و اعدة لإنتاج المضادات الحيوية.
\end{abstract}

